\title{
Tifus exantemático en Chile
}

\author{
ENRIQUE LAVAL R.
}

\section{Exantematic typhus in Chile}

La Historia de la Medicina en nuestra patria está muy ligada, desde la Colonia hasta probablemente los primeros 20 ó 30 años del siglo actual, a las enfermedades infecciosas que en forma epidémica asolaron el territorio. Esto vale, sobre todo, para la viruela y el tifus exantemático, que dieron origen a campañas casi heroicas del personal médico y sanitario.

Parece interesante señalar algunas consideraciones históricas sobre el tifus exantemático, que como muy bien lo escribió don Darío Osses "en ninguna parte del mundo se había logrado diferenciar de la fiebre tifoidea", a pesar de que ésta fue individualizada en 1818 por Bretonneau como entidad clínica y sus lesiones anatómicas descritas por Louis, en 1829.

Por supuesto que la confusión mencionada también existió en nuestro país.

Quizás la primera epidemia de tifus exantemático en Chile se produjo en el año 1554, en el Obispado de La Imperial y fue relatada por Góngora de Marmolejo, contemporáneo de Pedro de Valdivia.

Bajo el nombre araucano de "chavalongo" fueron englobadas por los españoles la fiebre tifoidea y el tifus exantemático en una sola entidad y así mencionadas hasta muy avanzado el siglo XIX.

En 1858 llegó al país, el doctor César Adami y en su tesis aprobada por la Facultad de Medicina para optar al título de Licenciado, dice: "por la práctica que he adquirido el uno y la otra son la misma enfermedad, con diferente gravedad y duración: el tifus de una duración más corta y la fiebre tifoidea de un curso más largo, ambas contagiosas en ciertas circunstancias y siempre producidas por las mismas causas". Más aún: en 1864 la Facultad llamó a concurso para un trabajo sobre "Fiebre tifoidea en Chile: sus causas, desarrollo, tratamiento y anatomía patológica" y fue premiada la memoria presentada por el alumno don Florencio Middleton sobre tifus exantemático, trabajo que mereció ser publicado en 1871 en los Anales de la Universidad de Chile.

Como es posible apreciar, la Facultad que premió este trabajo no hacía distinción alguna entre tifoidea y tifus exantemático. Anotemos que el profesor de Clínica Médica, doctor Schneider, publicó en 1868, en los mismos Anales, sus observaciones sobre el tifus, diciendo: "en mis apuntes he anotado, los primeros, los leves, como fiebre tifoidea y los segundos como tifus".

Es interesante recordar que la epidemia que describió el doctor Middleton en el concurso de 1864, fue extraordinariamente grave, con una letalidad de un $60 \%$, mayor que la de la viruela. Del informe presentado por el médico jefe de los hospitales de Santiago de la época, doctor don Lorenzo Sazié, se deduce claramente que la epidemia era de tifus exantemático: "esta fiebre -sin darle nombre- se comunica cuando hay aglomeramiento de personas en una misma habitación" y que las medidas higiénicas a tomar eran entre otras "mucho aseo, buen alimento y procurar evitar en lo posible las constipaciones". El propio Doctor Sazié murió a consecuencia del tifus exantemático el 30 de noviembre de 1865.

Después de este período desaparece casi completamente la palabra "tifus", para utilizarse exclusivamente la de fiebre tifoidea, olvidándose poco a poco el tifus exantemático, hasta el extremo de que en apuntes tomados en 1915 en la Cátedra de Patología Médica del Profesor Mauricio Brockmann se lee "que esta enfermedad no existe en el país".

Largo sería extenderse sobre este tema, pero es indiscutible que fue el doctor Arturo Atria Osorio el que confirmó en forma imbatible en 1918, la existencia del tifus exantemático en Chile, señalando claramente que siempre había habido casos de dicha enfermedad en el país, confundidos con los de fiebre tifoidea. No sólo se le acusó de "torpe y alarmista" sino que fue hostilizado y muy agraviado, pero el doctor Atria "fue una diáfana imagen de resistencia moral, de entereza y orgullosa noción de jerarquía".

\section{Bibliografía}

1.- Osses D. Rey, del Domingo No 855. El Mercurio. 08/ 05/1983

2.- Anales Chil. de Hist. de la Medicina. Vol. 1. 1964.

3.- Ferrer P. L. Historia General de la Medicina un Chile. Tomo 1. Impta. Talca. Chile. 1904.

4.- Grossi J. Reseña del Progreso Médico en Chile. Imprenta. de la Opinión. Valparaíso, Chile, 1895. 